\title{
ECONOMIC ANALYSIS OF MINI COAL GASIFIER (GasMin) COMMERCIALIZATION FOR SMALL AND MEDIUM INDUSTRIES (SMIS)
}

\author{
ANALISIS EKONOMI KOMERSIALISASI GASIFIER BATUBARA \\ MINI (GasMin) UNTUK INDUSTI KECIL DAN MENENGAH (IKM)
}

\author{
IJANG SUHERMAN \\ Research and Development Centre for Mineral and Coal Technology \\ Jalan Jenderal Sudirman 623 Bandung 40211 \\ Ph. (+6222) 6030483, Fax. (+6222) 6003373 \\ e-mail: ijang.suherman@esdm.go.id
}

\begin{abstract}
The Research and Development Centre for Mineral and Coal Technology (tekMIRA) has conducted a research on the GasMin since 2011, and currently enters the commercialization stage with a partnership scheme (KSO). This technology is one solution to solve the problem regarding the availability of cheap, clean and sustainable energy as well as environmentally friendly which is specifically intended for SMIs. Economic analysis is one of the activities in the commercialization process. From the analysis results, it can be seen that the Net Present Value of IDR is $808,273,705$, the Internal Rate of Return $28.68 \%$ per year and the Payback Period 3 years and 8 months. The three indicators show that the project is financially feasible, with a level of sensitivity to changes in production costs is up to a $5 \%$ increase, and a level of sensitivity to a decrease in selling prices is up to $-4 \%$. This economic analysis is very important for both tekMIRA as a technology provider to find out the value of technology, and its potential partners as input in making decisions as a partnership with tekMIRA.
\end{abstract}

Keywords: technology implementation, Small and Medium Industry, economics, commercialization.

\begin{abstract}
ABSTRAK
Pusat Penelitian Teknologi Mineral dan Batubara (tekMIRA) sudah melaksanakan penelitian tentang GasMin sejak 2011, dan saat ini sudah memasuki tahap komersialisasi dengan skema kemitraan (KSO). Teknologi ini merupakan salah satu solusi memecahkan permasalahan ketersediaan energi murah, bersih dan berkelanjutan serta ramah lingkungan yang diperuntukan khusus untuk IKM. Analisis ekonomi merupakan salah satu kegiatan di dalam proses komersialisasi. Dari hasil analisis dapat diketahui Net Present Value sebesar Rp 808.273.705, Internal Rate of Return 28,68\% per tahun dan Payback Period 3 tahun 8 bulan. Ketiga indikator tersebut menunjukkan bahwa proyek ini layak secara finansial, dengan tingkat sensitivitas terhadap perubahan biaya produksi hingga kenaikan 5\%, dan tingkat sensitivitas terhadap penurunan harga jual hingga -4\%. Analisis keekonomian ini sangat penting baik bagi tekMIRA sebagai penyedia teknologi untuk mengetahui besarnya nilai teknologi, maupun bagi calon mitra sebagai bahan masukan dalam pengambilan keputusannya bermitra dengan tekMIRA.
\end{abstract}

Kata kunci: implementasi teknologi, Industri Kecil Menengah, keekonomian, komersialisasi.

\section{INTRODUCTION}

National Energy Council (DEN) has predicted that energy consumption in Indonesia will keep increasing in the next few years. The growth of energy consumption has to be accompanied by the growth of national economy. Assuming realistic economic growth in 2018, the averaged of 5.6\%, energy growth is estimated at $7.2 \%$ (Dewan Energi Nasional, 2019). In line with this, Sugiyono (2014) suggests that to solve the energy problem, a government-released policy is needed.

Indonesia has to cut its oil consumption from 50 to 24 percent in 2025 . However, its oil 
consumption still increases and stays at 1.8 million barrel/day. In contrast, the growth of national oil production gradually decreases, around 400 to 500 barrel/day with an assumption that there is no new oil reserves found. The imbalance of oil consumption and production has resulted 60 percent energy deficit. Indonesia also has to face a deficit in natural gas production and is at risk for being unable to fulfill the national demand of natural gas in 2025. In this retrospect, coal gasification process has the potential as a solution to solve the current deficit problem in supplying the energy in both oil and gas consumption (Huda, 2016).

Indonesia has coal resources in Kalimantan, Sumatra and Papua. According to the data from Geological and Mineral Agency in 2018, Indonesia has 151.40 billion tons of coal resource, and 39.89 billion tons of coal reserves (Direktorat Jenderal Mineral dan Batubara, 2019). There is considerable amount of coal reserves for supplying energy needs until 2025. However, Indonesia does not yet optimize its large coal resources for the progress of its national economy. According to Haryadi (2011, 2015), 75 percent of raw coals are exported. Suherman (2009), Saleh (2012) and Suseno (2016) have proposed Domestic Market Obligation (DMO) and Fixed Price in Coal to address the imbalance in coal trade. Suherman (2015) also said that in order to achieve the target of national income from the coals, there is an urgent need of the policy to control the production and export in a coal trade. Indeed, the National Policy in Energy (KEN) has included the efforts of diversification in energy usage. However, its diversification will meet global concerns specifically in the issue of environmental degradation. Therefore, it is important to have an adequate technology to prevent harmful consequences towards the environment (Sugiyono, 2014).

The gasifier technology is one of the alternatives in attempting to reduce dependency of oil. The coals which have undergone gasification can be used for direct and indirect combustion (Nurhadi and Efendi, 2016). Coals which processed with gasification are more profitable and efficient compared to direct combustion (Kasdadi, 2012; Sofaeti et al., 2016). Actually, gasification process of coals which produces combustion gas is already implemented in several developed industries in Indonesia, for example in Java and Sumatra using fixed bed technology (Sodikin and Suprapto, 2012). However, its implementation is rather limited compared to the major industries.

Therefore, one of the efforts to reduce dependence on oil and gas is the use of gasification technology in SMIs, which called Mini Gasifier (GasMin).

The small and medium industries (SMIs) have strategic role. They have potential contribution to the economic growth and workforce absorption. In order to utilize the SMIs, providing cheap, clean and sustainable energy is necessary. At the moment, the SMIs is still using the energy subsidized by the government such as LPG and solar, and using raw oil which is categorized into dangerous and poisonous material or B3.

A GasMin coal is a reactor in the scale for SMls which produces gas from coal through a gasification process. GasMin has the potential to substitute energy for SMls and its process can help SMIs to cut 40 percent of their production cost. The GasMin helps pushing the development in downstream and service industries, solving the energy problem, workforce absorption, and others added values.

The Research and Development Agency of Energy and Mineral Resources through the Research and Development Centre for Mineral and Coal Technology (tekMIRA) has succeeded in recreating the GasMin. The original design is equipped with feeding rate of 4-10 kg/hours; consist of reactor (combustion room), ash room, and feeder room. The initial test for the design was to replace oil fuel (BBM) taken place in West Nusa Tenggara, 2011, within tobacco industries (Sofaeti and Daulay, 2014). From 2012 to 2016, the GasMin has been awarded as one of the best innovations among 105 best innovations and 11 distinguished creations of Anak Bangsa from the Ministry of Research and Development (Menristek). Based on the series of received development and awards, GasMin is ready for the challenge of the implementation within the national industries. In 2015, GasMin has implemented its pilot project in aluminum smelting, essential oil smelting, and tofu industries in Yogyakarta with each capacity of coal feed rate at 50 $\mathrm{kg} /$ hour; $30 \mathrm{~kg} / \mathrm{hour}$ and $20 \mathrm{~kg} / \mathrm{hour}$. In 2016, GasMin continued to create pilot project in 
Yogyakarta's aluminum industries (2 units) and batik industries with each capacity of coal feed rate at $30 \mathrm{~kg} /$ hour; $10 \mathrm{~kg} /$ hour and 20 $\mathrm{kg} /$ hour. This project has a yield positive outcome in adaptation and reducing the product costs. In addition, Efendi and Sofaety (2016) who conducted a kinetic analysis in gasification process, concludes that the maximum value of steam coal ratio at $0.06 \%$ can increase efficiency and increasing the amount of gas produced. Hopefully, the GasMin pilot projects in Yogyakarta can be used as a starting point for promotion, socialization, and commercialization in SMIs.

Based on the model in technology commercialization, the development of coal gasifier has reached the stage of product development and now at initial stage of commercialization. Therefore, a market analysis such as commercialization assessment and business valuation of GasMin coal are required. This is the same as the opinion of (Dasryanto and Purwanto, 2017).

The aim of analyzing financial aspect of this business is to decide a plan for investment and determine cost and profit value. Financial analysis is also used for mapping the ratio between the cost and income such as funds availability, capital venture for investment, project capability to return initial investment within specific time limit, and projecting the prospect of the business towards the future. (Umar, 2001).

Considering the conditions and used data that have not yet occurred, in this feasibility study many assumptions are used, among others in determining fabricator prices, production costs, and GasMin selling prices. To complete the economic calculation, a sensitivity analysis is also carried out. Sensitivity analysis explains how sensitive if there is a change in the variables taken into account. In addition, sensitivity analysis can also be used to manage the risks that occur if the project is realized. (Hidayat and Tantina, 2011).

\section{METHOD}

Survey and non-survey are used to get primary and secondary data for reinforce the analysis of economic and commercialization in GasMin Coal. The result from primary and secondary data will be further used for analysis and development of GasMin.

\section{Methods in Collecting Data}

The data collected in this research is both primary and secondary data, and also can be measured and interpreted in qualitative and quantitative. The primary data collected through a Focus Group Discussion (FGD) and survey to pilot project of GasMin implementation, as well as fabricator workshops. The secondary data were obtained through the literature review which focused in the matter of coal gasification technology.

\section{Methods in Interpreting and Analyzing Data}

The collected data is interpreted and analyzed with descriptive statistics and financial feasibility analysis. Microsoft Excel 2010 is used for supporting the interpretation and analyzing the collected data.

\section{Descriptive statistics}

Descriptive statistics is a set of methods that concerned in collecting and presenting the cluster data which turn into valuable information. Descriptive statistics provides central tendencies, distribution, and also pattern of data which then presented in the graph and table.

\section{Financial feasibility analysis}

Financial analysis is required in investment plan. From the financial aspect, the profitability is measured in investment plan using three alternative methods:

1. Net Present Value (NPV).

Net Present Value (NPV) is defined as present value from income cash flow after investment. Mathematically. The NPV is formulated:

$$
N P V(i)=\sum_{t=1}^{n} B_{t}(1+i)^{-t}-\sum_{t=0}^{n} C_{t}(1+i)^{-t}
$$

In this formula,

$$
\begin{aligned}
\mathrm{NPV}(\mathrm{i})= & \text { net profit value in present time } \\
& \text { for interest rate-i per number of } \\
& \text { period. } \\
\mathrm{Bt}= & \text { total net income or benefit for } \\
& \text { business at period } \mathrm{t} . \\
\mathrm{Ct}= & \text { total cost value (cost) for } \\
& \text { business at period } \mathrm{t} \text {. } \\
(1+\mathrm{i})-1= & \begin{array}{l}
\text { discount factor which } \\
\text { correction factor of time to }
\end{array}
\end{aligned}
$$


money value in $\mathrm{t}$ period with interest rate-i period $t$.

$\mathrm{i}=$ Present interest rates

$\mathrm{t}=$ time period of $-\mathrm{t}$

A business has economic feasibility if NPV (i) is larger than zero, which identical with profit rate is larger than zero.

2. Internal Rate of Return (IRR).

IRR is a probability index used in business analysis. Mathematically. The IRR is formulated as follows:

$$
I R R=i_{1}+\frac{N P V_{1}}{N P V_{1}-N P V_{2}}\left(i_{1}-i_{2}\right)
$$

In this formula,

$\begin{aligned} \mathrm{i}_{1}= & \text { Interest rate which generates } \\ & \text { positive NPV. } \\ \mathrm{i}_{2}= & \text { Interest rate which generates } \\ & \text { negative NPV. } \\ \mathrm{NPV}_{1}= & \text { positive NPV. } \\ \mathrm{NPV}_{2}= & \text { negative NPV. }\end{aligned}$

Feasibility level based on the IRR is determined by comparing existing interest rates. A business is feasible if the IRR value has more value than the existing interest rates.

3. Payback Period (PP).

PP determines the probability in return of investment within specific range of time. The PP is determined by calculating the time required, which will make accumulation of cash turn from negative to positive and the final value of capital gained will be the same as the initial investment. In other word, PP is the minimum time required for returning the initial investment in the form of cash flow based on total revenue minus total cost. Mathematically, $\mathrm{PP}$ is formulated below:

Payback Period $(\mathrm{PP})=$ $\frac{\text { Investment value }}{\text { Net Cash inflow }} \times$ period of time

\section{LITERATURE REVIEW}

\section{Technology of Coal Gasification}

Gas is produced from a chemical process of coal, bio-mass and wood charcoal with air as its reactant in gasifier reactor. It creates $40 \%$ of combustible gas such as carbon monoxide
(CO), hydrogen $\left(\mathrm{H}_{2}\right)$ and a little methane gas $\left(\mathrm{CH}_{4}\right)$. Other products are non-combustible gas such as nitrogen $\left(\mathrm{NO}_{2}\right)$, carbon dioxide $\left(\mathrm{CO}_{2}\right)$, and steam $\left(\mathrm{H}_{2} \mathrm{O}\right)$. Gasification process also creates a by-product such as tar, acid and particulate or dust. These compounds are pollutants and affect negatively to gas engine performance, especially for the gen-set. Therefore, it is important in designing gasifier to minimize these pollutants and to optimize the production of gas fuel in gasifier reactor. Chemical reaction in complete combustion between solid fuel and air produces $\mathrm{CO}_{2}$ and $\mathrm{H}_{2} \mathrm{O}$.

GasMin technology developed by tekMIRA is a fix bed up draft GasMin coal which is suitable for coal combustion using a furnace. GasMin consists of:

1. Scrapper functioned to adjust downward speed of the coals;

2. Feeder/hoper functioned as first gateway for coals to be processed;

3. Water level indicator, functioned as indicator for water level in water jacket;

4. Main hole, functioned as the first path for combustion and collating favorated plate and ash;

5. Bottom chambers, functioned for ash storage after combustion ended;

6. Steam pipe, functioned as the exit path for steam from water jacket;

7. Reactor, functioned as the combustion room and the place where the gasification process occur;

8. Air pipe, functioned as the gateway inside for water which has mixed with a steam supply.

\section{GasMin Utilization in the Pilot Project Implementation for SMIs}

\section{Aluminum smelting}

From the results of a survey conducted in Yogyakarta in 2014, the number of aluminum smelting industries reached 166 units. Usually, they use liquid fuel or gas. When the government adopted a policy to limit the usage of fossil fuel, some industries go bankrupt, and some of them still stay in the business using used oil. However, the used oil is considered hazardous because it contains metal droppings, additive, and other pollutants that can contaminate environment and endanger health (Sofaeti et al., 2016). There must be efforts to find an alternative energy that are environmentally friendly. For 
example, by using coals which has been converted into gas through gasification technology. In its application, it uses burner engineering and smelting furnace based on coal. In general, the improvement of smelting furnace can increase the efficiency in combustion and reduce its negative effect to environment. For all this time, the impact of combustion in aluminum smelting has become significant problem for businessman in non-ferro metal casting industry. The design of smelting furnace is referred to the current design in liquid petroleum gas (LPG) which shaped like a cylinder (Sundari, 2011). From the trials, it is known that to smelt the aluminum scrap with total weight of $30 \mathrm{~kg}$ needs 1 hour and 37 minutes and consume LPG as much as $3.60 \mathrm{~kg}$ or equivalent with 8 $\mathrm{kg}$ of coals. LPG for industries costs IDR $16,000 / \mathrm{kg}$ meanwhile coals only cost IDR $2,000 / \mathrm{kg}$. There is a significant cost reduction of IDR 41,600/production.

\section{Essential oil industry}

Boiler is a pressurized vessel with shape and size designed to create steam in clove distillation process used by many SMIs in producing essential oil. The steam is used as a medium for process in specific pressure level and also used as a medium for clove leaves distillation in a boiler with specific capacity. In order to change steam back to liquid form, the steam which contains oil streamed to condenser functioned as a cooler. Condensate is contained in gradual separator so the oil with high density can be separated from water and stays in the bottom of the bed. In order to produce essential oil with high quality and quantity of yield, a substantial amount of energy is required. For some time, craft SMls have been using waste from distillation process as fuel which is cheaper in terms of energy cost. Unfortunately, distillation process with waste from cloves leaves usually produce yield with quantity and quality below SNI, especially for total eugenol, bias index, and density. Eugenol consists of multiple carbon chains and aromatic hydroxyl group named phenol (Nuryoto, Jayanudin and Hartono, 2011). Satisfyingly, with the implementation of GasMin for essential oil, craftsmen could increase the quality of product (Figure 2).

\section{Tofu industry}

Steam production in tofu industry is quite modest, using used drums which functioned as boiler, and wood and sawdust as its fuel. Then, the steam transferred to the boiling bed and boiled the soybeans for \pm 20 minutes. The soybeans which have been cooked then filtered, and its filtrate is pressed with acetic acid solution and produce clumps of tofu. Later, this clump of tofu will be going to be cut and shaped.

The tofu industry in Kulon Progo has utilized GasMin coal to produce the steam through boiler and produce tofu which has the same quality and also to reduce cost in its fuel (Figure 3).

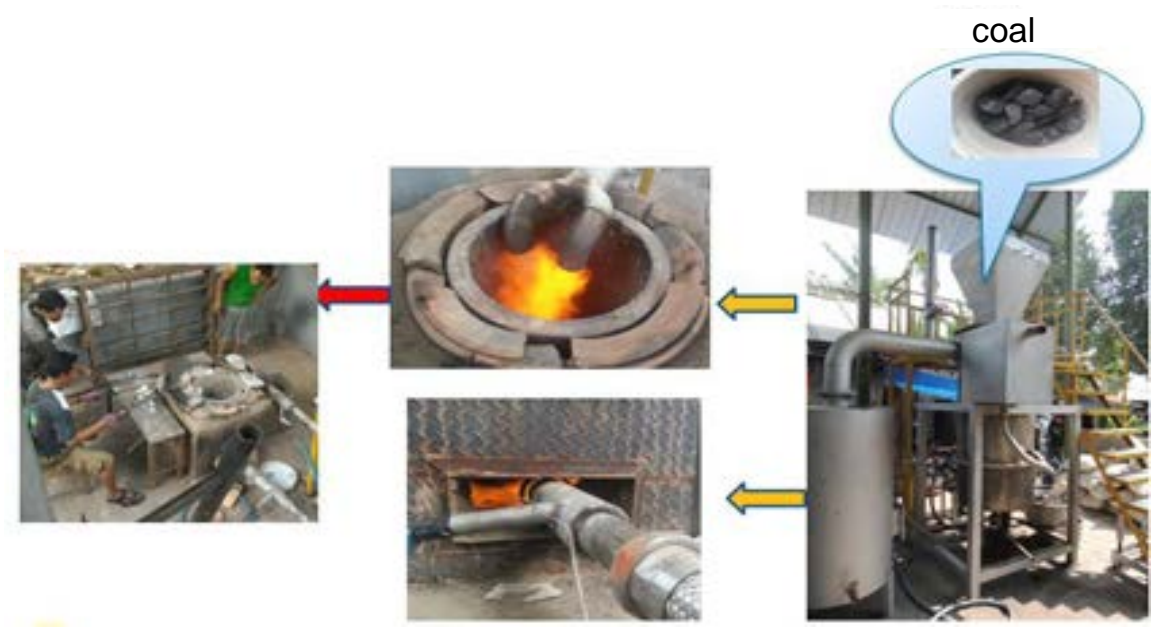

Figure 1. GasMin implementation in aluminum smelting in Yogyakarta. 


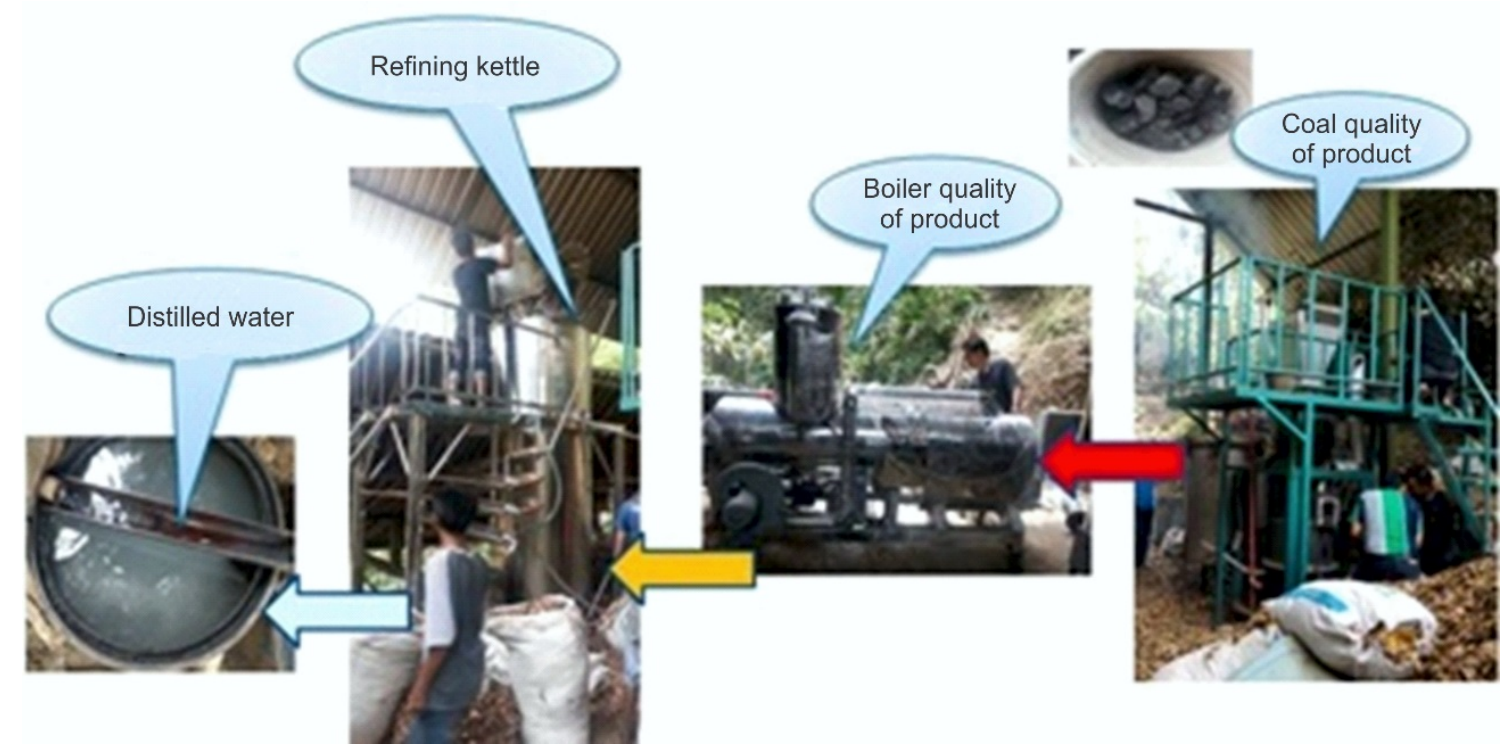

Figure 2. GasMin implementation on essential oil distillation in Kulon Progo
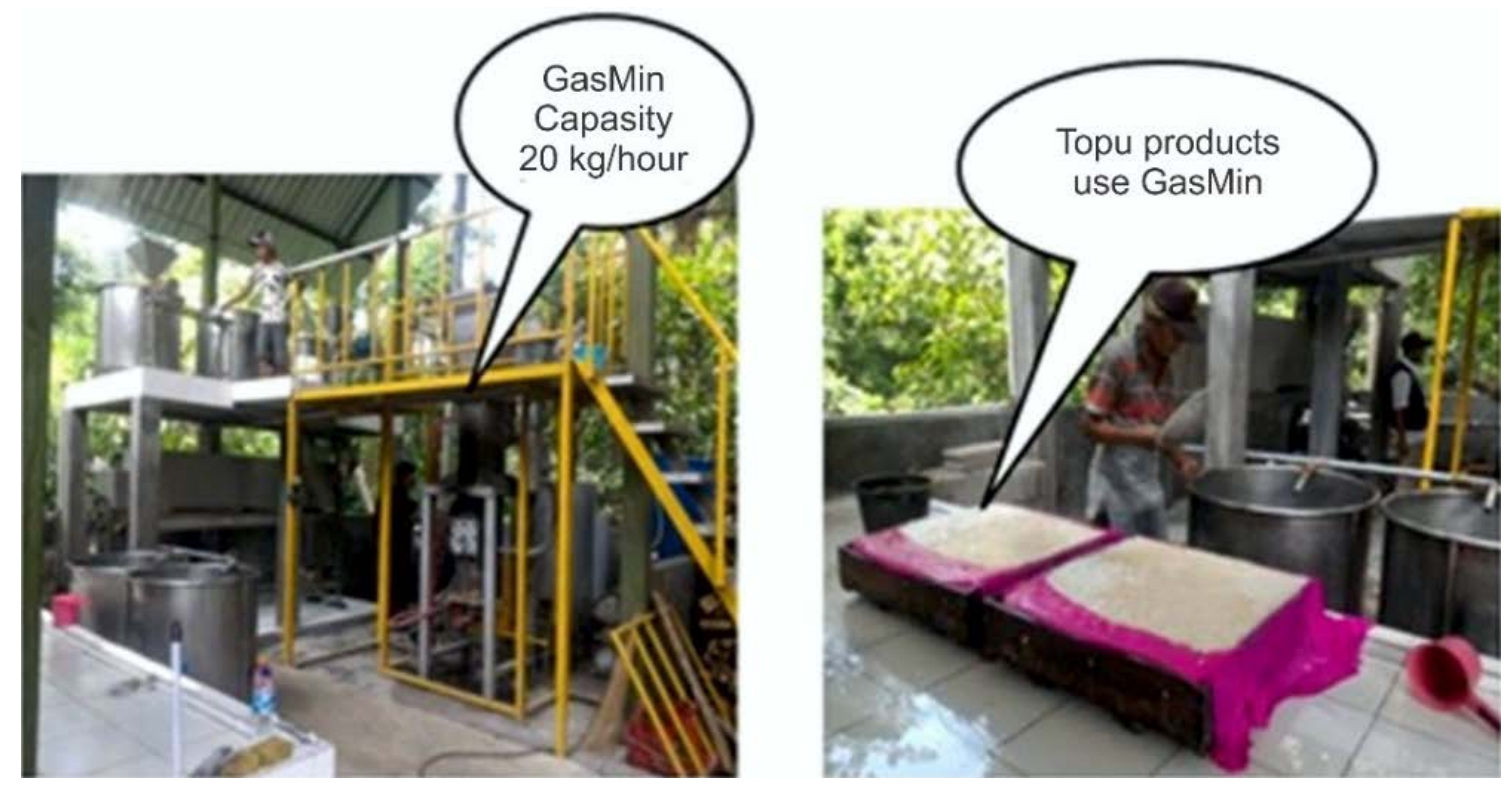

Figure 3. GasMin implementation on tofu industry in Kulon Progo

\section{Batik industry}

Batik stitching is a manual process to create batik by wax-resisting dyeing which attaches to batik decorative and soaking it in hot water so the wax comes to the surface. The water temperature used is around $60-70^{\circ} \mathrm{C}$. Woods or gas is often used for heating the water. For an experiment, SMIs in Sadewa, Sleman already used the GasMin with minimal application such as transferring gas from gasifier to furnace that contains hot water for stitching the batik (Figure 4). 


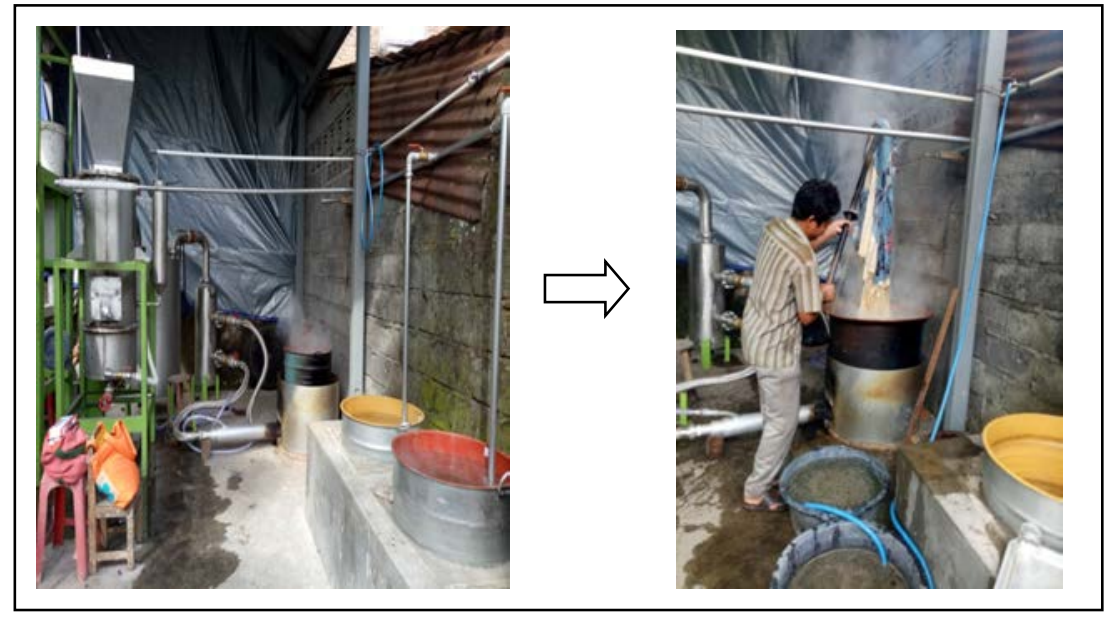

Figure 4. GasMin implementatio in the batik industry of Sleman

\section{RESULTS AND DISCUSSION}

After going through the product and market testing stage from 2011 to 2017, the next GasMin development stage is the commercialization stage.

In this stage, tekMIRA will explore the commercialization of GasMin through a partnership (KSO). For commercialization, calculating valuation technology or analysis of economic commercialization in the GasMin technology is needed. Economic analysis can create general overview in production and predict the cash flow of project in period of technological application. The result from economic analysis can be used to attract investor and create economic guidance in the research (Hudaya and Huda, 2014). The objective of analyzing financial aspect in business project is to make decision in investment plan through cost and benefit, comparing the cost between production and income, such as availability of funds, capital, financial capability for paying the payback period and capability in examining the growth of project and make decision based on it. (Umar, 2001; Hudaya and Umar, 2011).

The collected data from survey in Yogyakarta will be used as assumption for simulation in GasMin economic analysis. According to sampling frame data, FGD, and verification from SMls which have interest in buying GasMin, it can grasp the general overview of potential SMIs which will substitute their fuel to GasMin. Therefore, the business scenario of selling GasMin with assumption 48 units sold out per year is created.

\section{GasMin Market Potential}

In the context of commercialization of coal GasMin, in 2017, GasMin was promoted and promoted through FGDs in 4 (four) different places, namely in Sleman, Bantul, Gunungkidul and Kulon Progo Regencies. In the FGD, visiting the site was made to the pilot location for GasMin implementation and the exploration of interests through guided questionnaires. Then verification to several SMIs that are interested and intend to want to own and buy was conducted. With these activities, the potential markets of 517 SMIs units that consist of 215 food/ beverage industries, 139 units of batik, 56 units of pottery, 34 units of blacksmiths, 8 units of brick / tile, 5 units of lime burning and aluminum smelting 60 units can be sought. Then the selection process was made. It was based on the several criteria, namely energydense, boiler users, dryer oven users, fuel and gas users, and a continuous cooking process (minimum of 5 hours). The result shown that the GasMin market to be built are 53 SMIs units that consist of batik, food / drinks, bricks, wood processing, briquettes, lime burning, milk processing and aluminum smelting. The available markets that meet the requirements of the accessibility and qualifications of SMIs are 25 units, consisting of 8 units of batik artisans, 11 units of food / beverage SMIs, 3 units of brick / tile, 1 unit of wood processing, 1 unit of milk processing and 1 unit of aluminum smelting. The market that is served or the target market, which is part of the qualified available market that wants to be served, is 5 units of food I beverage, 4 units of batik, 1 unit of aluminum 
smelting. The results of the analysis of the measurement of the coal GasMin market in DIY are discussed in a separate article (Suseno and Suherman, 2020).

\section{Scenario of GasMin Business Model}

GasMin business model through partnership (KSO) is illustrated in Figure 5.

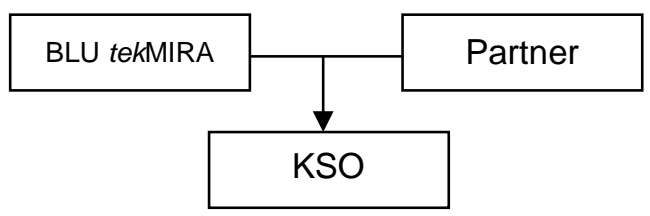

Figure 5. GasMin commercialization scheme through a partnership

The companies are part of cooperation model (KSO): which serve as Public Service Agency (Badan Layanan Umum, BLU) tekMIRA and investor (partner). In this GasMin business model, the BLU tekMIRA is the inventor or owner of GasMin technology, while the partner has funds to produce the GasMin and the working capital needed. To anticipate the development of GasMin technology that is needed by consumers (SMIs), BLU tekMIRA needs to do the $R$ \& $D$ of the technology to produce updated generation products with a better performance. Business partners need to have a capital to produce the GasMin or to pay the fabricator (the third party).

\section{Project Period and Production Level}

GasMin economic analysis simulation is based on the analysis of market potential above. It is assumed that the life of the project is in a 10-year period. The production level is assumed to be 48 units per year, consisting of 12 units of GTX10 type, 24 units of GTX30 and 12 units of GTX50. For the first year, it is assumed that the production level is only $75 \%$ or 36 units.

\section{GasMin Fabricator Prices}

GasMin fabricator price is a cost for thirdparty producers that fabricate GasMin according to the specific design by the BLU tekMIRA. Based on the surveys at Bekasi and Bandung, the price of GasMin fabrication for the types of GTX10, GTX30, and GTX50 is respectively IDR $17,600,000$, IDR $35,200,000$ and IDR $55,000,000$ per unit. This price includes $10 \%$ VAT.

\section{Operational Cost}

Operational cost for GasMin includes fabricator, labor cost, field operational cost (marketing and others), delivery and installation cost, and after sales service. The total operational cost is IDR $1,777,320,000$ in the first year (75\% of capacity) or IDR $148,110,000$ per month as shown in Table 1.

Table 1. Operational cost

\begin{tabular}{lccr}
\hline \multicolumn{1}{c}{ Variable } & $\begin{array}{c}\text { Unit Price } \\
\text { (IDR) }\end{array}$ & $\begin{array}{c}\text { Volume } \\
\text { (Unit) }\end{array}$ & $\begin{array}{c}\text { Value } \\
\text { (IDR) }\end{array}$ \\
\hline 1) GasMin Fabrication Cost & $17,600,000$ & 9 & $158,400,000$ \\
a. Type GTX10 & $35,200,000$ & 18 & $633,600,000$ \\
b. Type GTX30 & $55,000,000$ & 9 & $495,000,000$ \\
c. Type GTX50 & & & $1,287,000,000$ \\
\hline Total GasMin Fabrication Cost & & \\
\hline 2) Business Cost & $10,000,000$ & $360,000,000$ \\
a) Labor Cost & $5,000,000$ & \\
a. Manager & $5,000,000$ & \\
b. Production Section & $5,000,000$ & \\
c. Engineering Section & $5,000,000$ & \\
d. General Affair & $2 \%$ selling price & 36 & \\
e. Marketing Section & $1,800,000$ & $37,440,000$ \\
b) Operational Cost & $1.5 \%$ selling price & 36 & $64,800,000$ \\
c) Transportation and Installation Cost & & $36,080,000$ \\
d) After Sales Service & & & $490,320,000$ \\
\hline Total Business Cost & & & $1,777,320,000$ \\
\hline Total operational costs per year & & & \\
\hline Average monthly operational costs & & & \\
\hline
\end{tabular}




\section{Capital/Investment Cost}

In the GasMin business scheme mentioned above, the Partner needs to have a capital to hold GasMin which is self-produced or by the fabricator. The capital can be sourced from own capital and / or loan capital from banks. The amount of investment capital is assumed for the first 3 month, which is IDR 444,330,000 (Table 2).

Table 2. Total investment

\begin{tabular}{cc}
\hline Fund source & Value (IDR) \\
\hline Partner Capital (100\%) & $444,330,000$ \\
\hline Total & $444,330,000$ \\
\hline
\end{tabular}

\section{Royalty and Research and Development Expenses}

GasMin to be commercialized is the result of research and development in stages starting from the laboratory scale, prototype, pilot plant, demonstration to manufacturing scale. Therefore, in the GasMin business pattern, the BLU tekMIRA has a royalty right as the value technology. This royalty is used to improve the technology of the latest GasMin products. The royalty amount is assumed to be $3 \%$ of income.

\section{Selling Price}

GasMin Type GTX10, GTX30 and GTX50 selling prices are approximately IDR $25,600,000$, IDR $51,200,000$ and IDR $80,000,000$ per unit. However, this GasMin's commercialization business is taxed at $0.5 \%$ of turnover (income) (Presiden Republik Indonesia, 2018).

\section{Cash Flow}

Based on the magnitude of the cost components as above, it can be arranged the cash flow of GasMin business projects over a period of 10 years as can be seen in Table 3 .

\section{Net Present Value (NPV)}

Cash flow calculations will be used to calculate the NPV. With an annual deposit interest rate of $6.56 \%$ (Bank Indonesia, 2019) and an investment value of IDR 444,330,000, the NPV is IDR $884,361,837$ (Table 4).

\section{Internal Rate of Return (IRR)}

IRR value for 10 year with using the excel program is $28.68 \%$ per year (Table 4 ).

\section{Payback Period (PP)}

The payback period for GasMin project could be achieved within 3 years and 8 months (Table 5).

\section{Financial Feasibility Analysis}

Financial feasibility analysis is conducted to assess whether the business project is feasible or not feasible. In another definition, financial feasible study is conducted to examine if a project business (mostly investment) can yield success (Fauzi, 2007). The general aspect to determine a business project is feasible or not can be achieved through the calculation of Net Present Value (NPV), Internal Rate of Return (IRR), and Payback Period (PP).

The financial feasibility of GasMin coal is calculated through the business scenario with assumption that 48 unit is sold per year consisting of 9 GTX10 type units, 18 GTX30 type units and 9 GTX50 type in period of 10 years, whereas for the first year the sales rate is assumed to be $75 \%$. The total investment from Partners is IDR $444,320,000$, while the royalties for R\&D for BLU tekMIRA are $3 \%$ of revenue. Fabricator prices for these types are IDR 17,600,000, IDR 35,200,000 and IDR $55,000,000$ respectively, while the sales prices are IDR 25,600,000, IDR 51,200,000 and IDR $80,000,000$ per unit. The operational costs is IDR $444,330,000$ for the first year. The indicator of profit value, using the calculation NPV, IRR and PP is presented in Table 6.

From the indicator of profit value, it suggests that:

- NPV shown that the GasMin is economically profitable with positive values IDR 808,273,705.

- IRR around $28.68 \%$ per year is huge if compared to deposit interest rate of $6.56 \%$ a year.

- PP in 3 years and 8 months is considered fast gain for capital return.

With these calculations, GasMin coal business scenario is proven to be financially adequate. 
INDONESIAN MINING JOURNAL Vol. 23, No. 1, April $2020: 43$ - 56

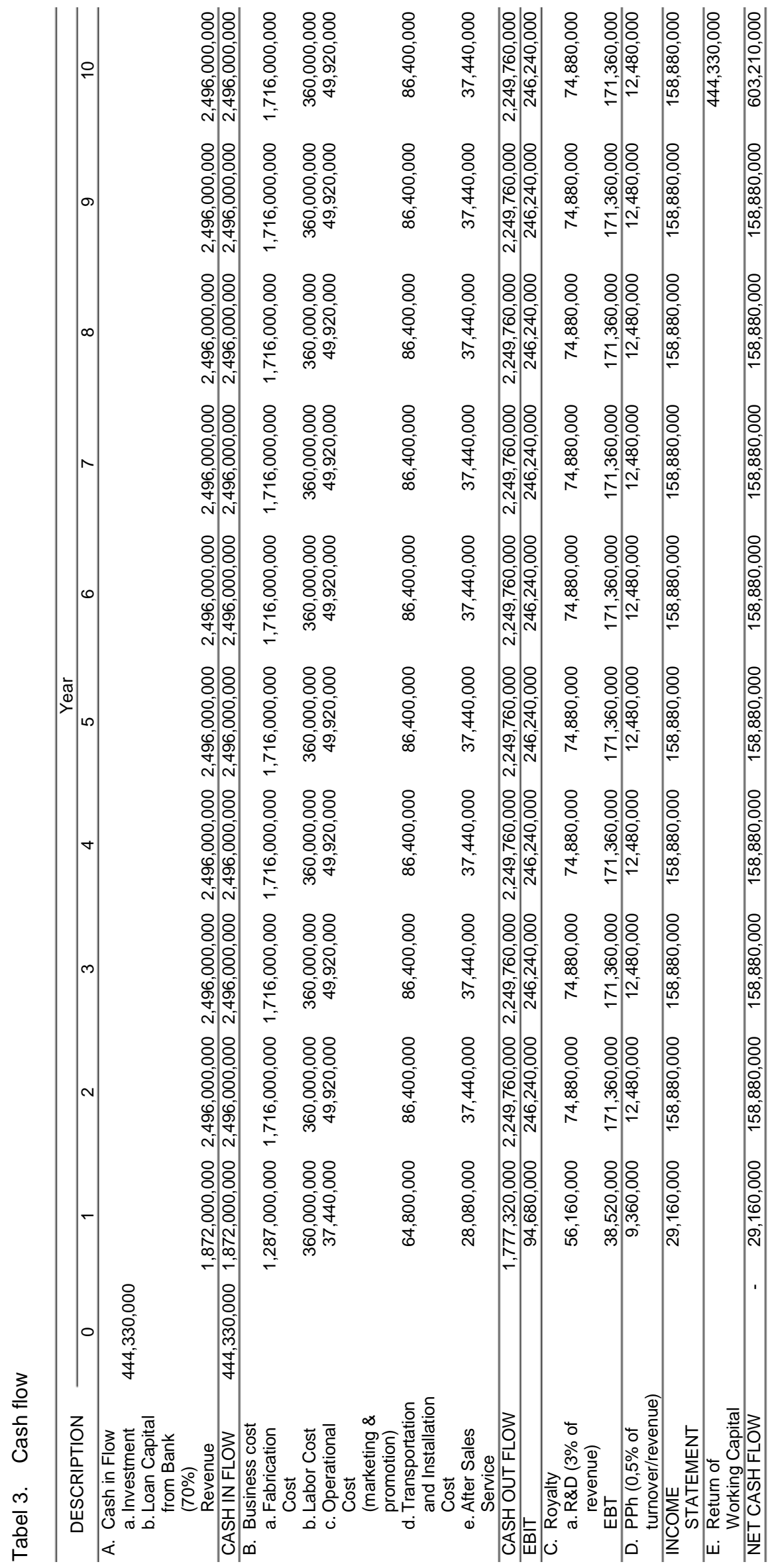


Table 4. Net present value

\begin{tabular}{cccc}
\hline Year & $\begin{array}{c}\text { Investment } \\
(\text { IDR })\end{array}$ & $\begin{array}{c}\text { Net Profit } \\
(\text { IDR })\end{array}$ & $\begin{array}{c}\text { Net Cash Flow } \\
(\text { IDR })\end{array}$ \\
\hline 0 & $-444,330,000$ & & $-444,330,000$ \\
1 & & $29,160,000$ & $29,160,000$ \\
2 & & $158,880,000$ & $158,880,000$ \\
3 & $158,880,000$ & $158,880,000$ \\
4 & $158,880,000$ & $158,880,000$ \\
5 & $158,880,000$ & $158,880,000$ \\
6 & $158,880,000$ & $158,880,000$ \\
7 & $158,880,000$ & $158,880,000$ \\
8 & $158,880,000$ & $158,880,000$ \\
9 & & $158,880,000$ & $158,880,000$ \\
10 & & $603,210,000$ & $603,210,000$ \\
\hline
\end{tabular}

Table 5. Payback period

\begin{tabular}{crc}
\hline Year & Net Cash Flow & $\begin{array}{c}\text { Present Value } \\
\text { at Deposit Interest Rate } 6.56 \%\end{array}$ \\
\hline 0 & $-444,330,000$ & $-444,330,000$ \\
1 & $29,160,000$ & $-415,170,000$ \\
2 & $158,880,000$ & $-256,290,000$ \\
3 & $158,880,000$ & $-97,410,000$ \\
4 & $158,880,000$ & $61,470,000$ \\
5 & $158,880,000$ & $220,350,000$ \\
6 & $158,880,000$ & $379,230,000$ \\
7 & $158,880,000$ & $538,110,000$ \\
8 & $158,880,000$ & $696,990,000$ \\
9 & $158,880,000$ & $855,870,000$ \\
10 & $603,210,000$ & $1,459,080,000$ \\
\hline
\end{tabular}

Table 6. Financial feasibility indicator and summary

\begin{tabular}{lll}
\hline No. & Parameter & Calculation \\
\hline 1 & Net Present Value (NPV) & IDR 808,273,705 \\
2 & Internal Rate of Return (IRR) & $28.68 \%$ per year \\
3 & Payback Period (PP) & 3 years and 8 monhts \\
\hline
\end{tabular}

\section{Sensitivity Analysis}

As calculated above, through the three indicators of financial feasibility, it shows that the GasMin commercialization project is financially feasible. Furthermore, it needs to be analyzed to determine the extent of its reliability or sensitivity. In other words, it is necessary to analyze the variables or factors that influence the financial feasibility of GasMin's commercialization. The sensitivity analysis will be carried out below by considering critical factors such as production costs and selling prices. Any changes in these critical factors will result in changes in financial parameters in determining the feasibility of commercialization of GasMin. The main financial parameters that will be used to determine the critical points of each factor are NPV and IRR, as well as the sensitivity analysis at UCG (Hudaya and Nugroho, 2015).

\section{Increase in Production Costs}

The price of GasMin Fabricators is quite critical considering the price of raw to increase. Likewise in terms of business costs can increase, whether it is from labor costs, marketing and operational costs, transportation and installation costs, or after sales service costs. To determine the reliability or sensitivity of the cash flow model above from the effect of changes in the variable production costs, carried out by increasing these costs by $1 \%$ in stages, until finally reaching the threshold value of financial viability. From these calculations the 
threshold for financial feasibility is achieved at a rate of increase in production costs of $5 \%$ (IDR 1,866,186,000), as shown in Figure 6.

\section{Decline in Selling Prices}

The selling price factor is also quite critical. It could be that the price offered is expensive, given that SMIs generally have capital and relatively low income. Therefore, it needs to be anticipated by lowering the price to the level that is still tolerated by the feasibility of the cash flow. To find out the reliability or sensitivity of GasMin's commercialization cash flow model from the effect of changes in the selling price variable, it is completed by gradually reducing the selling price by $1 \%$, until finally reaching the threshold value of financial viability. From the results of this calculation, the threshold of financial feasibility is achieved at a $-4 \%$ (IDR $1,797,120,000)$ decrease in selling prices, as shown in Figure 7.

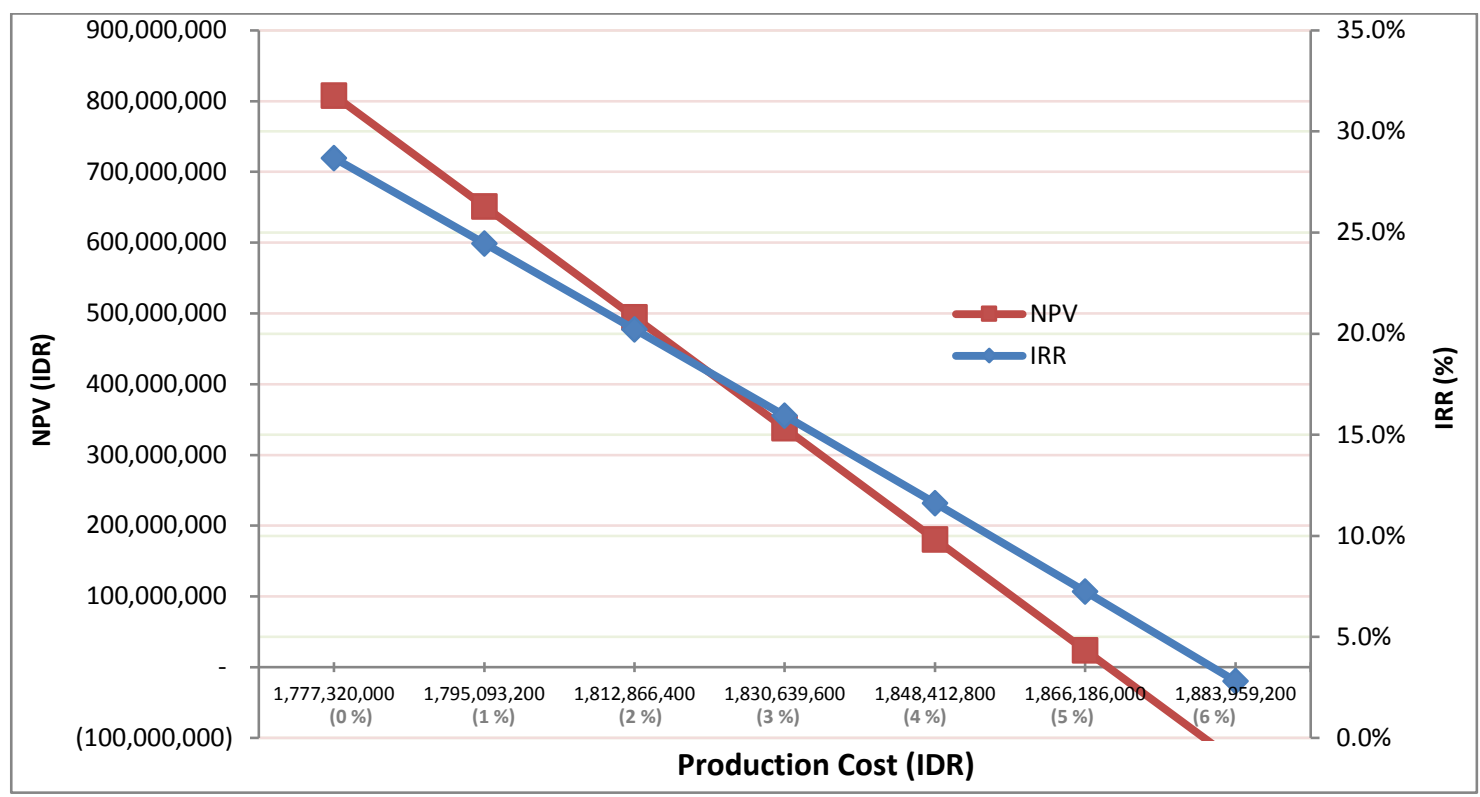

Figure 6. Sensitivity of an increase in production costs

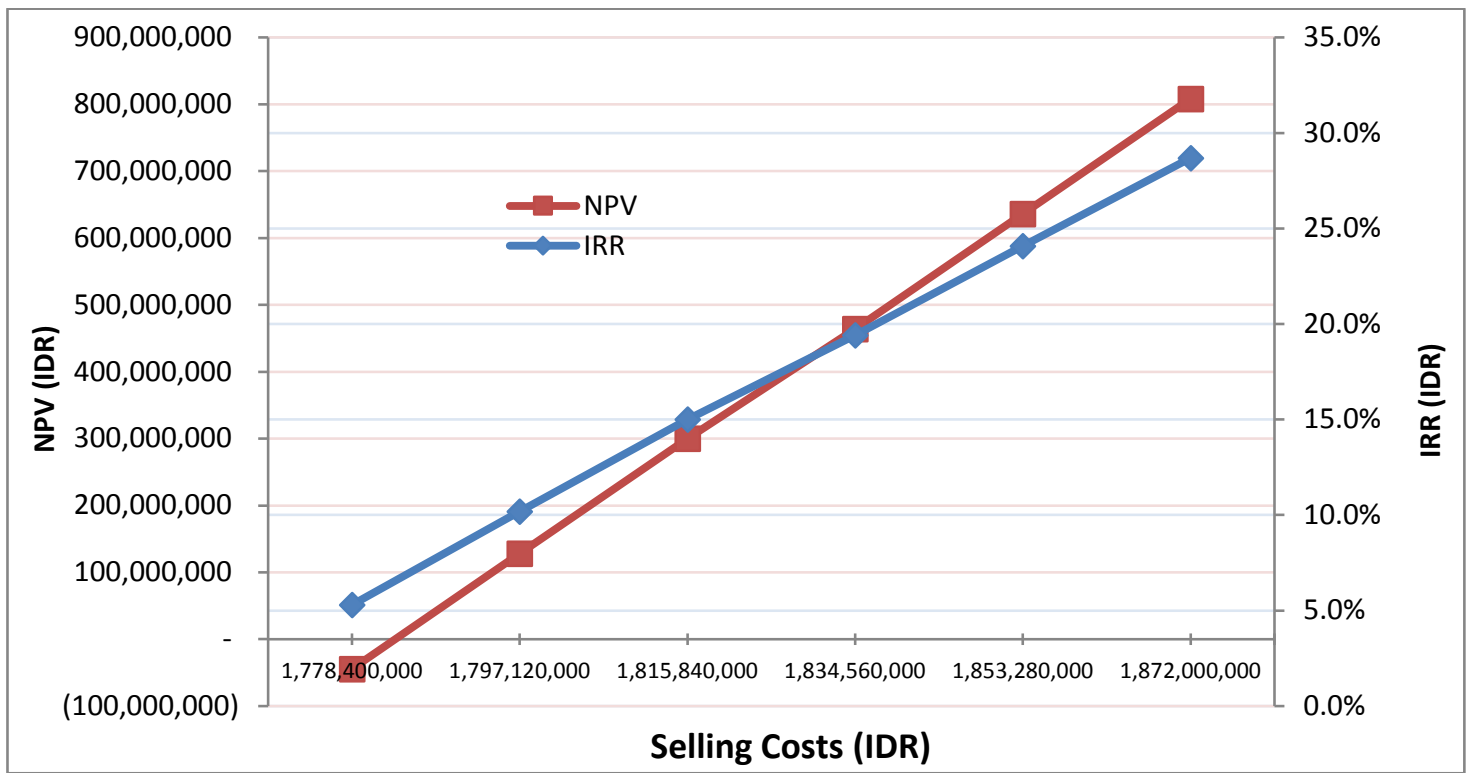

Figure 7. Sensitivity of a decline in selling prices 


\section{CONCLUSION AND SUGGESTION}

\section{Conclusion}

1. GasMin technology is an energy diversification effort that is proven to be environmentally friendly. Such a technology is suitable for use in SMIs to substitute subsidized LPG and diesel as well as substitute heavy oils which include fuels and poisons.

2. The business cooperation model can be carried out with the role of BLU tekMIRA in providing updated technology and partners as fabricators and providing operational costs.

3. GasMin's marketing is prioritized for certain SMIs such as the aluminum, batik, tea drying, and tofu industries.

4. GasMin's commercialization scenario model is declared financially feasible, and has a sensitivity level to changes in production costs up to an increase of $5 \%$, and a sensitivity level to a decrease in selling prices of up to $-4 \%$.

\section{Suggestion}

According to the economic analysis, FGD of GasMin commercialization, and sampling verification from SMIs which have profound interest in buying the GasMin, there is several suggestions that needs immediate follow-up:

a. Each SMIs has its own characteristics, so technically there will be some factors that need adjustment in each GasMin.

b. In general, SMIs views that GasMin price is expensive and not easy to obtain, therefore an efficient adjustment in production cost is needed for reducing GasMin selling price.

c. The successful implementation of GasMin was not only created by the result of research and technology development, but also caused by other aspects such as potential user in SMIs, coal distribution, and GasMin standardization. This is important for a sustainable implementation, and to ensure that the community, especially SMIs in DIY and other regions in Indonesia, can directly get benefit from GasMin implementation.

\section{ACKNOWLEDGEMENT}

The author would like to thank Drs. Ridwan Saleh, Drs. Triswan Suseno, and Agus
Prakosa, SE. for the support and cooperation during the field survey until the end of study.

\section{REFERENCES}

Bank Indonesia (2019) Suku bunga simpanan berjangka rupiah menurut kelompok bank dan jangka waktu, www.bi.go.id. Available at: https://www.bi.go.id/seki/tabel (Accessed: April 7, 2020).

Dasryanto and Purwanto, B. (2017) "Implementation evaluation and feasibility of Development of new energy of mini coal gasification on micro, small, and medium enterprise," Jurnal Aplikasi Manajemen, 15(3), pp. 432-443. doi: 10.21776/ub.jam.2017.015.03.08.

Dewan Energi Nasional (2019) Outlook energi Indonesia. Jakarta: Dewan Energi Nasional.

Direktorat Jenderal Mineral dan Batubara (2019) Pemenuhan kebutuhan batubara dalam negeri. Jakarta: Direktorat Jenderal Mineral dan Batubara.

Efendi, M. A. A. and Sofaety, Y. (2016) "Analyzing chemical kinetics of coal gasification in mini gasifier reactor," Indonesian Mining Journal, 19(2), pp. 107-117. doi: 10.30556/imj.Vol19.No2.2016.418.

Fauzi, A. (2007) "Analisis dan evaluasi aspek manajemen dalam studi kelayakan proyek," in Seminar Nasional Aplikasi Teknologi Informasi 2007. Yogyakarta: Seminar Nasional Aplikasi Teknologi Informasi, pp. I-(1-6).

Haryadi, H. (2011) "Analisis peranan mineral dan batubara bagi perekonomian nasional," Jurnal Teknologi Mineral dan Batubara, 7(3), pp. 122-136.

Haryadi, H. (2015) "Analisys of Indonesia's coal processing policy," in Santoso, B. et al. (eds.) Proceedings of tekMIRA Colloquium 2015. Bandung: Puslitbang tekMIRA, pp. 169-178.

Hidayat, L. and Tantina (2011) "Analisis sensitivitas sebagai faktor penting dalam suatu pengambilan keputusan investasi: Studi kasus pada PT Krakatau Daya Listri," Jurnal Ilmiah Ranggagading, 11(2), pp. 19.

Huda, M. (2016) "Kajian teknologi dan kebijakan underground coal gasification," in Santoso, B. et al. (eds.) Prosiding Kolokium Puslitbang Teknologi Mineral 
dan Batubara 2016. Bandung: Puslitbang tekMIRA, pp. 37-48.

Hudaya, G. K. and Huda, M. (2014) "Keekonomian gas bakar hasil proses UCG untuk energi pembangkit listrik," Mineral dan Energi, 12(2), pp. 29-35.

Hudaya, G. K. and Nugroho, A. (2015) "Sensitivity analysis on underground coal gasification (UCG) implementation in Indonesia," in Santoso, B. et al. (eds.) Proceedings of tekMIRA Colloqium 2015. Bandung: Puslitbang tekMIRA, pp. 45-49.

Hudaya, G. K. and Umar, D. F. (2011) "Pra studi kelayakan finansial pembangunan coal water mixture di Indonesia (Proses upgrading berteknologi hot water drying)," Jurnal Teknologi Mineral dan Batubara, 7(3), pp. 192-201.

Kasdadi, I. J. (2012) "Analisis sistem reaksi gasifikasi batubara dan biomassa (Study pemodelan \& simulasi)," Jurnal Fluida, 8(1), pp. 33-42.

Nurhadi and Efendi, M. A. A. (2016) "Utilization of coal gasification producer gas for power generation using $10 \mathrm{kw}$ spark ignition engine," Indonesian Mining Journal, 19(1), pp. 19-26. doi: 10.30556/imj.Vol19.No1.2016.362.

Nuryoto, Jayanudin and Hartono, R. (2011) "Karakterisasi minyak atsiri dari limbah daun cengkeh," in Prosiding Seminar Nasional Teknik Kimia "Kejuangan": Pengembangan Teknologi Kimia untuk Pengolahan Sumber Daya Alam Indonesia. Yogyakarta: UPN "Veteran" Yogyakarta, pp. C07-(1-4).

Presiden Republik Indonesia (2018) Peraturan Pemerintah Nomor 23 Tahun 2018 tentang pajak penghasilan atas penghasilan dari usaha yang diterima atau diperoleh wajib pajak yang memiliki peredaran bruto tertentu. Indonesia.

Saleh, R. (2012) "Domestic market obligation (DMO) policy and its implementation strategies," Indonesian Mining Journal, 15(1), pp. 42-58.

Sodikin, I. and Suprapto, S. (2012) "Karakteristik limbah cair proses gasifikasi batubara menggunakan sistem unggun-tetap," Jurnal Teknologi Mineral dan Batubara, 8(2), pp. 78-87.

Sofaeti, Y., Efendi, M. A. A., Yusnanto and Saputra, R. (2016) "Tantangan dan peluang teknologi gasifikasi skala industri kecil (Gasmin) untuk menggantikan bahan bakar minyak dan kayu bakar menuju komersialisasi," in Santoso, B. et al. (eds.) Prosiding Kolokium Puslitbang Teknologi Mineral dan Batubara 2016. Bandung: Puslitbang tekMIRA, pp. 13-20.

Sofaeti, Y. and Daulay, B. (2014) "Gasifierbatubara mini untuk menunjang ketersediaan energi pada UMKM di Daerah Istimewa Yogyakarta," in Prasetyadi, C. and Sulaksono, A. (eds.) 1st International Conference of Energy and 7th Indonesia - Malaysia Geoheritage Conference. Yogyakarta: UPN "Veteran" Yogyakarta, pp. 8-15.

Sugiyono, A. (2014) "Permasalahan dan kebijakan energi saat ini," in Prosiding Peluncuran Buku Outlook Energi Indonesia 2014 \& Seminar Bersama BPPT dan BKK-PI. Jakarta: Badan Pengkajian dan Penerapan Teknologi, pp. 9-16.

Suherman, I. (2009) "Masa kini dan masa depan batubara Indonesia," in Santoso, B. et al. (eds.) Prosiding Kolokium Pertambangan 2009 Pusat Penelitian dan Pengembangan Teknologi Mineral dan Batubara. Bandung: Puslitbang tekMIRA, pp. 5569.

Suherman, I. (2015) "Kajian percepatan peningkatan peran batubara dalam bauran energi nasional," Mineral dan Energi, 15(3), pp. 83-97.

Sundari, E. (2011) "Rancang bangun dapur peleburan aluminium bahan bakar gas," Jurnal Austenit, 3(1), pp. 17-26.

Suseno, T. (2016) "Analisis implementasi kebijakan penetapan kebutuhan dana persentase minimal penjualan batubara untuk kepentingan dalam negeri," in Santoso, B. et al. (eds.) Prosiding Kolokium Puslitbang Teknologi Mineral dan Batubara 2016. Bandung: Puslitbang tekMIRA, pp. 133-146.

Suseno, T. and Suherman, I. (2020) "Analisis pengukuran pasar gasmin batubara di Daerah Istimewa Yogyakarta," Jurnal Teknologi Mineral dan Batubara, 16(1), pp. 47-56. doi: 10.30556/jtmb.Vol16.No1.2020.1042.

Umar, H. (2001) Studi kelayakan bisnis: Teknik menganalisis kelayakan rencana bisnis secara komprehensif. 2nd ed. Jakarta: Gramedia Pustaka Utama. 